\title{
ASPECTOS POLÊMICOS DA COMPRA E VENDA COM RESERVA DE DOMÍNIO
}

\author{
Bruno Leonardo Câmara Carrá \\ Doutor em Direito Civil pela USP com estudo pós-doutoral \\ na Universidade de Bolonha (Itália). Juiz federal no Ceará. \\ Professor do Curso de Direito da FA7. \\ brunoleonardo5@uol.com.br \\ SUMÁRIO: Introdução. 1. A Cláusula de Reserva de \\ Domínio no Código Civil de 2002. 2. Mora e Inadimplemento. \\ 3. Propriedade Fiduciária, Alienação Fiduciária em Garantia e \\ Reserva de Domínio. 4. Alienação da Coisa pelo Comprador. \\ Conclusões. Referências.
}

Resumo: O presente artigo aborda as principais características da cláusula de reserva de domínio contidas no Código Civil de 2002, diferenciando-a, inclusive, da propriedade fiduciária e do contrato de alienação fiduciária em garantia. Por outro lado, realiza-se o estudo dos aspectos considerados polêmicos da cláusula de reserva de domínio, assim considerados aqueles para os quais a doutrina e a jurisprudência nacionais ainda não apresentam soluções de consenso, razão pela qual o trabalho recorrerá aos modelos europeus com os quais o Direito brasileiro guarda destacada afinidade na tentativa de obter respostas concretas aos problemas suscitados.

Palavras-chave: Cláusula de reserva de domínio. Código Civil de 2002. Propriedade fiduciária e contrato de alienação fiduciária em garantia. Aspectos polêmicos. Direito comparado.

\section{INTRODUÇÃO}

Situada topograficamente como modalidade especial da venda a crédito, costuma-se conceituar a reserva de domínio como o pacto adjeto através do qual o comprador, nada obstante já estar na posse da coisa vendida, somente adquire sua efetiva propriedade no momento em que o preço é integralmente pago.

Diferencia-se assim da compra e venda em simples prestações, porquanto a transferência do domínio não acontece no momento da tradição e sim com a quitação plena do contrato.

Há certo consenso doutrinário de que sua presença consagra a existência de uma condição suspensiva à compra e venda pura e simples ${ }^{1}$. Entretanto, deve-se ter em conta que tal condição incide na execução do contrato, que de regra será diferida no tempo e no espaço (PEREIRA, 2007, p. 229).

\footnotetext{
${ }^{1}$ A "Inclina-se a doutrina para a teoria da venda sob condição suspensiva, conquanto censurável por atribuir a um dos elementos essenciais do contrato, precisamente o preço, a natureza jurídica de condição. O pagamento do preço é a principal obrigação do comprador, a contraprestação devida ao vendedor, não sendo possível considerá-la acontecimento incerto, pois o devedor tem a necessidade jurídica de satisfazê-lo. Por outro lado, se condição fora, no sentido técnico do vocábulo, seria meramente potestativa, porque o cumprimento da obrigação ficaria ao arbítrio exclusivo do devedor." (GOMES, 1994, p. 264).
} 
$\mathrm{Na}$ verdade, parece que a reserva de domínio encerra, ao mesmo tempo, uma condição suspensiva, no que se relaciona à aquisição da propriedade do bem vendido e também uma condição resolutiva do contrato, caso o pagamento das prestações não venha a se verificar (LISBOA, 2005, p. 322).

Discute-se, contudo, se é um de instituto recente, como afirmam alguns (WALD, 2004, p. 354). Para outros, havia indícios, ou fragmentos de sua existência no Digesto (PEREIRA, 2007, p. 232). Há mesmo quem defenda seu pleno conhecimento e uso sistemático pelos romanos (MONTEIRO, 2003, p. 119).

Ferrara observa que no Direito justinianeu era possível chegar-se aos mesmos efeitos do que agora se chama pacto de reserva de domínio, mas que essa expressão, pactum reservati dominii, tão ao gosto dos doutrinadores recentes, nunca chegou a ser cunhada em qualquer uma das fases do Direito romano. ${ }^{2}$

Seja instituto recente ou remoto, foram as vicissitudes da economia moderna, fundada no crédito, que tornaram esse instituto (e outros semelhantes, como o da propriedade fiduciária) de extrema importância para os ordenamentos jurídicos contemporâneos, como já deixava transparecer os considerandos da Lei espanhola de 1965:

\begin{abstract}
Es incuestionable la importancia que alcanzado el crédito en los tiempos actuales, constituyendo una de las bases en que se asienta el desarrollo de la vida social no sólo en los aspectos industrial y comercial, sino en el de la vida familiar y doméstica. Una de las modalidades del crédito es el de la venta, de bienes muebles corporales a plazos, que viene a ser factor importante en los planes de desarrollo económico y cuya extensión es característica de la vida moderna. Hasta ahora estas operaciones se han venido realizando dentro de las normas generales de nuestro ordenamiento jurídico, pero la realidad reclama imperiosamente una regulación especial que establezca los justos limites de facilidad y garantía para compradores y vendedores.
\end{abstract}

\title{
1 A Cláusula de Reserva de Domínio no Código Civil de 2002
}

No Direito anterior, vale dizer, quando ainda vigorava o Código Civil de 1916, a cláusula de reserva de domínio importava verdadeiro contrato atípico, muito embora seu nome fosse referido na legislação. É que, nada obstante a referência tipológica, não havia um trato ordenado da matéria, o que afasta a conclusão de que, verdadeiramente, houvesse um regramento legal a respeito do tema, o que veio a acontecer apenas com o advento do Código Civil de $2002^{3}$.

Diz o art. 521 do Código Civil que na venda de coisa móvel, pode o vendedor reservar para si a propriedade, até que o preço esteja integralmente pago.

Pergunta-se se poderia, como permite expressamente o art. 409 do Código Civil de Portugal, que apenas parte do preço ficasse garantido pela cláusula especial. A despeito do silêncio da legislação brasileira, o princípio da autonomia da vontade parece perfeitamente aplicável na ocasião, de modo que as partes poderiam convencionar a incidência apenas parcial do instituto (LÔBO, 2010, p. 261).

2 "L'abolizione di ogni distinzione tra res mancipi e res nec mancipi nel diritto giustinianeo rese anche per le prime utile la riserva de proprietà per escludere la fides de pretio. Ma anche qui non v'è parola del pactum reservati dominii: vi sono per ottenere questo effetto le solite forme del precario e della localione" (FERRARA, 1934, p. 10).

3 Esse fenômeno, qual seja, da atipicidade, embora tenha sido o contrato expressamente referido na legislação, decorre do fato de que o importante para que se classifique o contrato (ou uma subespécie contratual, como, no caso, a compra e venda com reserva de domínio) está mais relacionado com a existência de normas que regulamentam e sistematizam o instituto, que, propriamente, com o nome dado pela legislação (cf. MESSINEO, 1986, pp. 378-379). 
Mais adiante, o art. 524 agrega que a transferência de propriedade ao comprador dá-se no momento em que o preço esteja integralmente pago. Desse modo, a aquisição da propriedade pelo comprador independe de nova declaração de vontade pelas partes (GOMES, 1994, p. 262).

Diz ainda o art. 524 que, pelos riscos da coisa, responde o comprador a partir de quando lhe foi entregue. Essa disposição, em tudo semelhante ao que dispõe o Código Civil italiano, traz como consequência prática a impossibilidade de o vendedor poder solicitar reforço de garantia caso a coisa perca seu valor em razão de seu uso racional pelo comprador.

Igualmente, veda ao vendedor a possibilidade de postular qualquer aumento no preço, embora formalmente a coisa permaneça sua, por eventuais benfeitorias ou, simplesmente, pela valorização eventual da coisa. Ver-se que o legislador cuidou de dar definição tipológica ao pacto acessório de reserva de domínio em forma bastante próxima àquela que consta do Código Civil italiano (art. 1.523).

Dispôs ainda o Código Civil (art. 523) que não pode ser objeto de venda com reserva de domínio a coisa insuscetível de caracterização perfeita, para estremá-la de outras congêneres. Vale dizer, o bem não pode ser fungível (MONTEIRO, 2003, p. 120).

Solução diversa e bem mais ampla adotou o Código Civil francês, que admite no art. 2.369 o uso da cláusula para bens móveis fungíveis (além de bens imóveis), desde que o credor possa exercer o restante de seu crédito sobre bens de mesma natureza e mesma qualidade sob a posse do devedor, ou terceiros por sua conta. ${ }^{4}$

Aliás, mais recentemente o legislador nacional também alterou essa regra em relação ao contrato de alienação fiduciária (art. 66-B, da Lei no 4.728/65, com a redação que deu a Lei no 10.931/04), passando expressamente a permitir que o bem fungível pudesse ser dado em garantia fiduciária.

As visíveis semelhanças estruturais entre ambos os contratos deviam fazer com que tal regra permissiva fosse igualmente estendida para os contratos de compra e venda com reserva de domínio e mesmo para a propriedade fiduciária prevista no art. 1.361 do Código Civil (que também se limita a bens infungíveis).

Estabelece também o atual art. 522 do Código Civil que a cláusula de reserva de domínio deve obrigatoriamente ser estipulada por escrito e dependerá de registro no domicílio do comprador para valer contra terceiros.

Essa solução afasta-se da sistemática disciplinada pelos códigos alemão e italiano. O primeiro, como se viu, sequer exige a forma escrita, contentando-se com a retenção do título de domínio pelo comprador. O segundo exige a forma escrita, mas deixa a possibilidade de que seja ela redigida em momento posterior ao da venda. ${ }^{5}$

No caso brasileiro, portanto, é possível afirmar que o pacto adjeto de compra e venda com reserva de domínio exige forma própria para sua validade (art. 104 do CC), e somente seu registro é condição apenas de eficácia perante terceiro.

Por isso mesmo, embora não registrado, pode ser oposto ao outro concertante, mas não aos terceiros de boa-fé. Por sinal, esse sempre foi o posicionamento do Superior Tribunal de Justiça sobre o assunto, antes mesmo da entrada em vigor da lei civil de $2002^{6}$.

4 "La propriété réservée d'un bien fongible peut s'exercer, à concurrence de la créance restant due, sur des biens de même nature et de même qualité détenus par le débiteur ou pour son compte".

5 "La riserva della proprietà è opponibile ai creditori del compratore, solo se risulta da atto scritto avente data certa anteriore al pignoramento." (Art. 1524, primeira parte, do Código Civil Italiano).

6 Cf. nesse sentido: STJ. REsp 17.546/SP, Rel. Ministro NILSON NAVES, TERCEIRA TURMA, julgado em 08/06/1992, DJ 03/08/1992, p. 11310. 
O Direito Civil italiano, por sinal, introduziu disposição que limita a necessidade de inscrição do contrato no registro competente apenas aos que tenham por objeto máquinas e cujo valor supere a importância de $€ 15,49^{7}$.

De modo semelhante, Antunes Varela defende, em face da redação do art. 409 do Código Português, a desnecessidade de publicidade para fins de eficácia contra terceiros da cláusula adjeta relativa a bens que por sua natureza não são ordinariamente objeto de registro. Nesses casos, “a reserva vale em relação a terceiros, por simples convenção das partes” (VARELA, 1991, p. 309).

Semelhante solução, vale dizer, a relativização do registro em face do valor do contrato não poderá ser adotada de lege lata, em face da redação do art. 522 do Código de 2002.

Entretanto, parece ser medida razoável quando o valor da coisa for baixo, ou, eventualmente, por ausência de atrativos econômicos na realização dessa formalidade. Seria o caso, parece, das vendas de eletrodomésticos, ou utensílios do lar em geral.

A defesa mais ampla do crédito, em nosso pensar, estaria a recomendar a ausência de registro com a validade do pacto adjeto contra terceiros, isto é, com a eventual assunção dos riscos pelo subcomprador, em bens destituídos de elevado valor.

\section{Mora e InADIMPLEMENTO}

Da Teoria Geral das Obrigações retiramos o conceito de mora e inadimplemento. Como sabido, ambos os termos significam o não cumprimento a modo, lugar e tempo em conformidade com o vínculo obrigacional que foi estabelecido.

Não cumprimento, portanto, é termo que funciona como gênero das espécies em comentário. Isso porque há dois casos visivelmente distintos de descumprimento (ou não cumprimento) tendo em vista a utilidade da prestação.

No primeiro caso, embora descumprida, a obrigação ainda persiste, pois seu cumprimento ainda é fisicamente possível e útil ao credor, que, uma vez paga a indenização correspondente ao atraso respectivo, ainda se considera interessado na entrega da prestação. ${ }^{8}$

No segundo, não. Inadimplemento, ou não cumprimento total, é termo que denota o próprio perdimento do interesse do credor na prestação. Embora até possível materialmente, ela já não se apresenta como útil se considerados os motivos que orientaram o surgimento do vínculo obrigacional. ${ }^{9}$

Embora o vigente Código Civil (assim como seu antecessor, de 1916) não tenha explicitamente utilizado a palavra atraso para demonstrar que o descumprimento foi apenas parcial (art. 394), a referência à ideia de manutenção do vínculo em razão da utilidade da prestação em face do contexto da obrigação resta expressamente mencionada no parágrafo único do art. 395 do CC.

\footnotetext{
7 "Se la vendita ha per oggetto macchine e il prezzo è superiore agli € 15,49 la riserva della proprietà è opponibile anche al terzo acquirente, purché il patto di riservato dominio sia trascritto in apposito registro tenuto nella cancelleria del tribunale nella giurisdizione del quale è collocata la macchina, e questa quando è acquistata dal terzo, si trovi ancora nel luogo dove la trascrizione è stata eseguita." (Art. 1524, segunda parte, do Código Civil Italiano).

8 “[...] há situações de mero retardamento, dilação ou demora na prestação. A prestação não é executada no momento próprio mas ainda é possível, por continuar a corresponder ao interesse do credor. Pode este ter sofrido prejuízo com o não cumprimento em tempo oportuno; mas a prestação ainda mantém no essencial a utilidade que tinha para ele" (VARELA, 1999, p. 64).

9 "Há casos em que a prestação, não tendo sido efetuada, já não é realizável no contexto da obrigação, porque se tornou impossível ou o credor perdeu o direito a sua realização, ou porque, sendo ainda materialmente possível, perdeu o seu interesse para o credor, se tornou praticamente inútil para ele." (VARELA, 1999, p.63).
} 
Os conceitos de mora, ou seja, o não cumprimento parcial, e inadimplemento total são particularmente interessantes para o pacto adjeto com cláusula de reserva de domínio.

\subsection{Constituição do devedor em mora}

Inicialmente, diz o art. 525 do Código Civil que o vendedor somente poderá executar a cláusula de reserva de domínio após constituir o comprador em mora, mediante protesto do título ou interpelação judicial. ${ }^{10}$

A jurisprudência, já com base no art. 1.071 do CPC, sempre destacou que o protesto do título era suficiente para a constituição do devedor em mora, não havendo necessidade de interpelação, salvo se assim optasse o credor. Tal entendimento foi, já na vigência do Código de 2002, confirmado reiteradas vezes pelo Superior Tribunal de Justiça ${ }^{11}$.

Recentemente, o Superior Tribunal de Justiça autorizou, a nosso sentir corretamente, a hipótese de incidência do art. 525, admitindo a simples notificação extrajudicial como meio igualmente adequado para comprovação da mora ${ }^{12}$.

Embora o art. 525 do CC diga que são apenas duas as formas de comprovação da mora nos contratos de compra e venda gravados com o pacto adjeto em estudo (protesto e interpelação judicial). O mesmo Código, na parte geral das Obrigações, preconiza solução distinta.

Com efeito, regulamentando a matéria em absoluta simetria com o Código Civil de 1916 (art. 960), a vigente lei civil diz inicialmente que se a prestação for positiva e líquida, o inadimplemento no seu termo constitui, de pleno direito, o devedor em mora (art. 397).

Trata-se de positivar a bem conhecida parêmia do dies interpellat pro homine, pois a obrigação a cargo do devedor encontra-se perfeitamente definida, não havendo necessidade de realizar mais qualquer outro ato para que tome ciência de seu dever jurídico.

Já hipótese referida no parágrafo único do art. 397 traduz exatamente o oposto. Não existindo "dies" previamente estabelecido, ou seja, inexistindo termo, a mora se constitui mediante interpelação judicial ou extrajudicial.

Vê-se com facilidade que enquanto a parte geral do Código permite a interpelação extrajudicial, o já referido art. 525 do CC limita a constituição da mora ao protesto e à interpelação judicial. Entretanto, não se vislumbra qualquer razão de cunho ontológico para limitar a possibilidade de comprovação da mora através da notificação simplesmente extrajudicial.

Se sistematicamente comparados, ambos os institutos se equiparam para fins eminentemente práticos. Em sentido contrário, há defensores da falta de certeza que a simples notificação extrajudicial engendra, pelo que não se poderia equipará-la ao protesto (MONTEIRO, 2003, p. 124).

Além disso, parece induvidoso que o protesto traduz posição jurídica bem mais delicada para o devedor, quer em virtude da publicidade que opera ${ }^{13}$, quer pelos efeitos que pode

10 Como sabido, o protesto é, em definição legal, o ato formal e solene pelo qual se prova a inadimplência e o descumprimento de obrigação originada em títulos e outros documentos de dívida (art. 1o da Lei 9.492/97).

11 Cf. STJ. REsp 762.799/RS, Rel. Ministro LUIS FELIPE SALOMÃO, QUARTA TURMA, julgado em 16/09/2010, DJe 23/09/2010.

12 Cf. STJ. REsp 897.593/SP, Rel. Ministro ALDIR PASSARINHO JUNIOR, QUARTA TURMA, julgado em 17/03/2011, DJe 24/03/2011.

13 Inclusive perante terceiros que podem consultar o Tabelião de Protesto de Títulos, nos termos do art. 27 da Lei no 9.492/97: “Art. 27. O Tabelião de Protesto expedirá as certidões solicitadas dentro de cinco dias úteis, no máximo, que abrangerão o período mínimo dos cinco anos anteriores, contados da data do pedido, salvo quando se referir a protesto específico." 
gerar. Por constituir meio menos gravoso, não há como negar-se que tanto o protesto como a notificação (ou interpelação) extrajudicial se configuram como meios hábeis para a constituição do devedor em mora.

Suscita maior interesse, entretanto, eventual cláusula contratual na compra e venda com reserva de domínio que dispensasse a constituição em mora com referência à regra estabelecida no caput do art. 397 do CC. Tratar-se-ia de disposição válida? Parece que não, pelo menos se deseja o credor exercendo seus direitos de retomada da coisa com propriedade resolúvel. É certo que a gravidade dos efeitos de uma demanda petitória, com o consequente perdimento da coisa, exige que o devedor seja prévia e formalmente constituído em mora.

Essa conclusão, por outro lado, encontra suporte no fato de o legislador não desconhecer que nesses tipos de negócio não há ordinariamente dúvidas quanto à certeza das obrigações do devedor na medida em que as prestações são de antemão por ele conhecidas, salvo a hipótese admissível em teoria, mas não verossímil na prática, de uma venda dessa natureza em que coubesse ao devedor eleger o momento do pagamento.

Por outro lado, raciocínio idêntico é adotado no que se relaciona ao contrato de alienação fiduciária em garantia de contrato com o qual o pacto adjeto de reserva de domínio guarda similitude.

Com efeito, a mora decorrerá do simples vencimento do prazo para pagamento e poderá ser comprovada por carta registada expedida por intermédio de Cartório de Títulos e Documentos ou pelo protesto do título, a critério do credor.

Como explica Orlando Gomes, a regra é híbrida. Embora vencível ex re, é necessária a documentação da mora, que já aconteceu (GOMES, 1975, p. 100). Nisso, diferencia-se a regra em análise daquela constante do Parágrafo Único do art. 397 do Código Civil.

Ao contrário do que parece, portanto, o verbo poderá (ainda na redação do que diz o art. 2o, § $2^{\circ}$, do Decreto no 911/69) não indica faculdade quanto à possibilidade de constituição em mora, mas apenas quanto ao meio, como deixa patente a reiterada jurisprudência do Superior Tribunal de Justiça ${ }^{14}$.

Desse modo, embora a constituição em mora do devedor possa e deva ser desburocratizada, não deve ser eliminada, assemelhando-se ao modelo alemão que preconiza a necessidade de anterior rescisão do contrato para a execução do pacto adjetivo de reserva de domínio (§ 449, 02, BGB).

Sob tal perspectiva, não se devem interpretar de modo literal as expressões protesto e interpelação judicial, servindo como tal qualquer ato legítimo e documentado por autoridade pública de que o devedor apresenta-se impontual ${ }^{15}$.

Caso, entretanto, opte o credor pela simples execução da dívida, a leitura dos artigos 1.070 e 1.071 do Código de Processo Civil deixam transparecer a desnecessidade do protesto (RIZZARDO, 2010, p. 380) ${ }^{16}$.

14 Cf. STJ. AgRg no Ag 1315109/RS, Rel. Ministro RAUL ARAÚJO, QUARTA TURMA, julgado em 01/03/2011, DJe 21/03/2011.

15 Assim, por exemplo, se já foi o devedor validamente citado em anterior demanda, dispensa-se nova constituição em mora, porque ela já existiu, como já decidiu certa vez o Tribunal de Justiça de São Paulo.

16 Entendendo serem ações com pressupostos processuais distintos e, portanto, permitindo que a execução estivesse munida apenas do título executivo extrajudicial (contrato de compra e venda com reserva de domínio, se presente os requisitos de certeza, liquidez e exigibilidade): Agravo Regimental no 992.09.076364-4/50000, da Comarca de São Paulo. Órgão julgador: 25a Câmara de Direito Privado do Tribunal de Justiça de São Paulo. Relator: Desembargador Sebastião Flávio. Data do julgamento: 20 de julho de 2010. 


\subsection{Inadimplemento e Purgação da Mora}

Embora documentada a mora, certamente podem existir causas que elidam a conclusão de que houve inadimplemento, quer parcial, quer total do contrato.

É possível pensar hipoteticamente em várias situações de "mora accipiens", como em um crediário que somente possa ser pago no próprio estabelecimento empresarial do credor, mas que esteja momentaneamente fechado (balanço, greve, reforma etc.).

Sendo ainda um contrato comutativo e oneroso, a cláusula de reserva de domínio não afasta a incidência da tradicional regra da exceptio non adimpleti contractus. Assim, mesmo tendo sido documentada a mora pelo credor, o devedor sempre poderá desconstituir a presunção relativa que se forma por esse ato formal.

Assim, por exemplo, o Tribunal de Justiça de São Paulo considerou que eventual venda de estabelecimento comercial com cláusula de reserva de domínio não poderia ser executada se "os autores confessadamente não cumprem prestação crucial ao equilíbrio do contrato, qual a de apresentar a quitação dos débitos trabalhistas e tributários que constam em seu nome e no de sua empresa"17.

Silenciou o Código Civil em relação à materialidade da mora propriamente dita, ou seja, não fez qualquer referência ao montante de prestações em aberto necessárias para a configuração da mora ou do inadimplemento.

$\mathrm{O}$ art. 1525 do Código Civil italiano, regulamentando o assunto, assegura a possibilidade de conservação do ato obrigacional, impedindo sua resolução pelo vendedor, se a impontualidade é de apenas uma prestação e o valor em atraso não supera a oitava parte do preço ${ }^{18}$.

O próprio legislador nacional adotou critério assemelhado quando regulamentou o compromisso de compra e venda de bens imóveis, estabelecendo o Decreto-Lei no 58/37 em seu art. 14 que a resolução somente teria lugar trinta dias após a constituição em mora.

De lege ferenda, e tendo por fundamento a visível função social desta modalidade de contrato (e não apenas a necessidade, legítima, de estabelecer instrumentos juridicamente condizentes com a proteção do crédito), parece ser aconselhável a disciplina da cláusula adjeta da reserva de domínio nos moldes acima destacados.

Não havendo disposição que imponha restrições à configuração do momento material do inadimplemento, pressupõe-se que o atraso em apenas uma prestação importará o vencimento antecipado do contrato. Por sinal, isso já é expressamente previsto no art. $2^{\circ}, \S 3^{\circ}$, do Decreto $n^{\circ}$ 911/69.

Por essa razão, parece correta a doutrina que diz não existir impedimento na inserção, pelas partes, de outras hipóteses de vencimento antecipado do concerto (WALD, 2004, 536). Se decorrerem de fato anterior, não se haverá de cogitar a necessidade de nova constituição em mora, em perfeita harmonia com a norma já constante do art. $2^{\circ}, \S 3^{\circ}$, do Decreto ${ }^{\circ}$ 911/69.

Por outro lado, note-se que não se está falando de purga da mora. Diferentemente do Decreto no 911/69, o Código Civil não traçou qualquer regra sobre o tema. Aparentemente,

17 Apelação no 9067762- 07.2005.8.26.0000, da Comarca de São Paulo. Órgão julgador: 9a Câmara de Direito Privado do Tribunal de Justiça de São Paulo. Relator: Desembargador Piva Rodrigues. Data do julgamento: 1 de março de 2011.

18 "Nonostante patto contrario, il mancato pagamento di una sola rata, che non superi l'ottava parte del prezzo, non dà luogo alla risoluzione del contratto, e il compratore conserva il beneficio del termine relativamente alle rate successive." 
portanto, poder-se-ia supor que seria inviável a purgação da mora. Com o protesto documentando a mora ex re, estaria o contrato resolvido.

Nada obstante, será no Código de Processo Civil que se encontrará norma própria sobre o tema. Diz, com efeito, a segunda parte do $\S 2^{\circ}$ do art. 1.071 do CPC que, optando o devedor pela retomada do bem, o comprador, que houver pago mais de $40 \%$ (quarenta por cento) do preço, requerer ao juiz que lhe conceda trinta dias para reaver a coisa.

Essa disposição, sem embargo, deve ser revisitada em face das novéis alterações feitas pela Lei $n^{0}$ 10.931/04 em relação ao contrato de alienação fiduciária em garantia, para que não se estabeleçam soluções incompatíveis para estruturas negociais em quase tudo assemelhadas.

A jurisprudência, por isso mesmo, vem entendendo que é perfeitamente possível a aplicação analógica das regras contidas no Decreto n 911/69 sobre purgação da mora a várias espécies contratuais que envolvam o financiamento na aquisição de bens e produtos. ${ }^{19}$

Assim, independentemente do valor já pago, poderia o comprador purgar a mora. Em relação ao previsto no art. 1.071 do CPC, tratar-se-ia de regra aplicável apenas aos que já liquidaram o percentual de quarenta por cento do preço, a fim de obter a dilação de trinta dias para a purgação da mora.

O importante, entretanto, é ter em conta que o não pagamento de quarenta por cento do preço não impede a possibilidade de purgação da mora, desde que imediata, ou pelo menos no prazo de cinco dias a que alude a vigente redação do art. $3^{\circ}, \S 2^{\circ}$, do Decreto ${ }^{\circ}$ 911/69, dada pela Lei $n^{\circ} 10.931 / 94$.

\subsection{Ações Processuais e Retenção de Valores}

Nos termos do art. Art. 526, com a verificação da mora debitoris, pode o credor mover ação de cobrança das prestações vencidas e vincendas e o mais que lhe for devido; ou poderá recuperar a posse da coisa vendida.

Aqui, é necessária a remessa ao que diz a legislação processual, embora não se vá abordar o assunto desde o ponto de vista procedimental, tendo em vista os limites deste trabalho.

Abrem-se para o vendedor, nitidamente, duas possibilidades: a) a cobrança pura e simples do débito, na forma de executivo extrajudicial (art. 1.070 do CPC); b) retomada da coisa, que em princípio é a busca e apreensão, mas como o próprio Código fala em reintegração de posse posteriormente à arrecadação da coisa, costuma-se denominá-la de reintegração de posse (art. 1.071 do CPC).

Quer se denomine a ação referida no art. 1.071 do Código de Processo Civil de busca e apreensão ou de reintegração de posse, percebe-se com facilidade que ela é dotada de procedimento diverso tanto de uma como de outra, cuja observação é imperiosa para o juiz, já que isso irá refletir-se em etapas posteriores.

É o caso da prévia vistoria na coisa, mencionada no $\S 1^{\circ}$, que tornará mais ágil a liberação das parcelas eventualmente retidas pelo vendedor, como se verá logo baixo.

19 Nesse sentido: Agravo de Instrumento n 990.09.304736-5, da Comarca de Campinas. Órgão Julgador: 29ª Câmara de Direito Privado do Tribunal de Justiça de São Paulo. Relator: Desembargador Oscar Feltrin. Data do Julgamento: 09 de dezembro de 2009. 
Ainda em conformidade com a iterativa jurisprudência, as ações referidas no art. 1.070 e 1.071 do Código de Processo Civil, do mesmo modo que ocorre com as ações do Decreto $\mathrm{n}^{\circ} 911 / 69$, não podem ser manejadas concomitantemente ${ }^{20}$.

Optando pela recuperação da posse da coisa vendida, diz o art. 527 que é facultado ao vendedor reter as prestações pagas até o necessário para cobrir a depreciação da coisa, as despesas feitas e o mais que de direito lhe for devido.

Diz ainda que excedente será devolvido ao comprador; e o que faltar lhe será cobrado, tudo na forma da lei processual.

O Código Civil erigiu norma que evita o enriquecimento indevido do vendedor. Veio a fazê-lo, entretanto, de forma indireta, ou seja, estabelecendo o direito de retenção do saldo já quitado até o encontro de contas em relação ao valor depreciado e demais custos de cobrança ${ }^{21}$.

Parece sintomático que o Código primeiro quis garantir o direito de retenção por parte do credor, sugerindo que essa operação tem prevalência sobre a outra (entregar o excedente, quando houver).

Se a compra e venda envolver uma relação de consumo, não há dúvidas de que a restituição das prestações, naquilo que for devido, está amparada na regra constante do art. 53, $\S 1^{\circ}$, do CDC que considera nula qualquer cláusula que estabeleça a perda total das prestações pagas em benefício do credor que, em razão do inadimplemento, pleitear a resolução do contrato e a retomada do produto alienado (MARQUES, 2002, p. 496).

Entretanto, não se vislumbra necessariamente a nulidade de pleno direito de uma eventual disposição contratual que estipule a perda das prestações pagas, o que, inclusive, pode vir disciplinado na forma de cláusula penal como já chegou a ser aceito em mais de uma ocasião pelo Tribunal de Justiça de São Pauloº 22 .

Uma eventual cláusula penal, entretanto, deve harmonizar-se necessariamente com as disposições da Lei no 1.521/51, que trata dos crimes contra a economia popular, pois tipifica como delito "descontar das prestações pagas, nas vendas com reserva de domínio, quando o contrato for rescindido por culpa do comprador, quantia maior do que a correspondente à depreciação do objeto."

Desse modo, a perda integral das prestações deve ser apreciada caso a caso, limitada, sempre, ao montante da depreciação da coisa e despesas correlatas. A solução, com as necessárias vênias, parece injusta na medida em que exclui o cômputo de eventuais perdas e danos do vendedor, relativamente às parcelas vencidas.

Essa talvez seja a melhor interpretação a ser dada ao crime tipificado pela Lei $\mathrm{n}^{\circ} 1.521 / 51$, sob pena de retirar do credor uma válida oportunidade de ressarcir-se de todas as consequências geradas com o inadimplemento.

20 Cf. STJ. REsp 576.081/SP, Rel. Ministro LUIS FELIPE SALOMÃO, QUARTA TURMA, julgado em 25/05/2010, DJe 08/06/2010.

21 Nesse mesmo sentido é a disposição constante do art. 1526 do Código Civil Italiano: "Se la risoluzione del contratto ha luogo per l'inadempimento del compratore, il venditore deve restituire le rate riscosse, salvo il diritto a un equo compenso per l'uso della cosa, oltre al risarcimento del danno."

22 Apelação n 992.06.037000-8, da Comarca de São José dos Campos. Órgão julgador: 28a Câmara de Direito Privado do Tribunal de Justiça de São Paulo. Relator: Desembargador Júlio Vidal. Julgado em 10 de agosto de 2010; Agravo de Instrumento no 990.10.379689-6, da Comarca de Leme. Órgão julgador: $31^{\text {a }}$ Câmara de Direito Privado do Tribunal de Justiça de São Paulo. Relator: Desembargador Paulo Ayrosa. Julgado em 25 de novembro de 2010. 
De toda forma, o devedor sempre poderá valer-se da regra prevista no art. 413 do Código Civil, que diz poder a multa penal ser reduzida equitativamente pelo juiz se a obrigação principal tiver sido cumprida em parte, ou se o montante da penalidade for manifestamente excessivo, tendo-se em vista a natureza e a finalidade do negócio ${ }^{23}$.

Finalmente, na situação oposta, isto é, no caso de valorização da coisa, será o credor beneficiado por ela. Nessa hipótese, obviamente, não terá que devolver esse excedente ao comprador na medida em que, com a resolução do contrato, a coisa volta a lhe pertencer.

Tal se dá em razão da regra constante da segunda parte do art. 524, que estabelece correrem pelo comprador os riscos da coisa desde que essa lhe é entregue. Se a coisa vem a se valorizar, experimentará ele os ganhos sem que possa, inclusive, o vendedor cobrar qualquer diferença. Mas, se em razão de culpa sua o contrato é resolvido, deve responder ao vendedor pela depreciação da coisa.

\section{Propriedade Fiduciária, Alienação Fiduciária em Garantia e Reserva de Domínio}

A disciplina da cláusula de reserva de domínio é bastante próxima do contrato de alienação fiduciária em garantia e da propriedade fiduciária, com quem comparte em boa medida seus elementos identificadores.

Surge o problema de saber se, em razão do regramento estabelecido pelo Código Civil, ainda continuam vigentes as regras que disciplinam o pacto adjeto de reserva de domínio, ou se todos constituem um único sistema. Esses institutos aproximam-se ainda mais quando considerada a hipótese prevista no art. 528 do Código Civil que será adiante examinada.

Contudo, já desde a redação dada pelo art. $1^{\circ}$ do Decreto 911/69, que alterou o art. 66 da Lei ${ }^{\circ} 4.728 / 65$, a alienação fiduciária em garantia é o negócio jurídico que tem por objeto transferir ao credor o domínio resolúvel e a posse indireta da coisa móvel alienada, independentemente da tradição efetiva do bem, tornando-se o alienante ou devedor em possuidor direto e depositário com todas as responsabilidades e encargos que lhe incumbem de acordo com a lei civil e penal.

Tradicionalmente, considera-se existir um constituto possessorio, pelo que é possível ao fiduciante (devedor) transferir a propriedade e a posse indireta ao fiduciário, independentemente de tradição. De consequência, resolve-se o domínio do credor (financiador) quando lhe for pago integralmente o valor do preço.

Analisada a estrutura do contrato da alienação fiduciária em garantia, percebe-se que as semelhanças com o pacto adjeto de compra de domínio são apenas parciais e que, na realidade, os elementos constituidores de um e outro contrato são visivelmente distintos. Ambos valem-se de institutos muito próximos, a saber, a propriedade resolúvel (art. 1.359 do Código Civil) e a propriedade fiduciária (art. 1.361 do Código Civil), sendo, na realidade, esta uma espécie daquela que funciona como gênero.

Entretanto, a propriedade fiduciária em geral traduz uma alienação de domínio apenas provisório, porquanto deverá ser revertida ao próprio alienante. Na medida em que a

23 Solução essa que se harmoniza ainda com aquela dada pelo Código Civil italiano (art. 1526, segunda parte), que aceita a validade da cláusula de perda, mas dá ao juiz poderes para relativizá-la conforme as circunstâncias:

"Qualora si sia convenuto che le rate pagate restino acquisite al venditore a titolo d'indennità, il giudice secondo le circostanze, può ridurre l'indennità convenuta". 
causa do contrato é seu uso apenas como instrumento de garantia, cria-se um efeito simetricamente contrário ao pacto de reserva de domínio.

De fato, na compra e venda com reserva de domínio, a condição é suspensiva relativamente à aquisição da propriedade pelo devedor. Na alienação fiduciária em garantia, há uma condição resolutiva atinente à perda do domínio pelo credor (RODRIGUES, 2003, p. 183; GOMES, 1975, p. 28).

Por sinal, deve ser esclarecido, como adverte autorizada doutrina, que não se confundem o sistema de propriedade fiduciária previsto no Código Civil e a alienação fiduciária em garantia prevista na legislação especial, tendo cada um, por sua vez, âmbito próprio de aplicação.

Surgem dois sistemas de propriedade fiduciária: o do art. 1.361 do Código Civil (chamado também de paritário) e o art. 66-B da Lei n ${ }^{\circ} 4.728 / 65$ para o segundo, o que é particularmente explicitado pelo art. 1.368-A, do Código Civil (RESTIFFE NETO \& RESTIFFE, 2007, p. 22).

Tirando, entretanto, circunstâncias peculiares e específicas (como a aplicação da multa processual a que se refere o art. $3^{\circ}, \S 6^{\circ}$, do Decreto $n^{\circ} 911 / 69$ no caso de improcedência da ação de busca e apreensão pelo credor fiduciário), tais institutos são, em essência, os mesmos.

Analisando especificamente as relações entre a alienação fiduciária em garantia e a reserva de domínio, costuma-se dizer que aquela pode ter como objeto bens imóveis, enquanto a outra estaria restrita a bens móveis (GAGLIANO \& PAMPLONA FILHO, 2008, p. 69).

Apesar de verdadeiro o argumento, é de se observar que a alienação fiduciária de coisas imóveis tem regência em diploma e em regras distintas (v. Lei no 9.514/97).

Mais interessante ainda, a propriedade fiduciária dita paritária não pode, igualmente, ser aplicada para a propriedade imóvel nos termos do art. 1.361 do Código Civil, que se restringe aos bens móveis e fungíveis.

Assim, é apenas acidental a opção do Direito brasileiro pela inaplicabilidade da cláusula de reserva de domínio aos bens imóveis, porque tal limitação, em princípio, não é da essência do pacto adjeto (BESSONE, 1960, p. 263). Tanto assim que vários ordenamentos jurídicos explicitamente a admitem, como o francês e o português.

Sobre o argumento de que a reserva de domínio sempre envolve uma venda direta, opina-se no sentido de que a hipótese mencionada no art. 528 do Código Civil (mediante financiamento de instituição do mercado de capital) vem a esvaziá-lo, porquanto permite seu uso também em financiamentos.

Finalmente, a alienação fiduciária em garantia possui o peculiar mecanismo da caracterização do devedor como depositário, o que não existe na compra e venda com reserva de domínio.

Há, entretanto, quem defenda que, se expressamente pactuado, o comprador poderá ser considerado como depositário, isto é, o contrato de compra e venda poderá existir de modo coligado com um contrato de depósito (VENOSA, 2005, p. 101).

Apresenta-se opinião no sentido contrário, porque a similitude da compra e venda com reserva de domínio, no ponto, com a alienação fiduciária em garantia permite que sejam importadas as conclusões que Álvaro Villaça Azevedo reiterada e sistematicamente fazia em relação à impossibilidade de conversão do devedor em depositário infiel: 
A conclusão, portanto, é de que não existe, na alienação fiduciária em garantia, a figura de depositário, pois, na verdade, o alienante (fiduciante) é o proprietário, porque, desde o início negocial, sofre ele o risco da perda de objeto. Ninguém será condenado, portanto, como depositário infiel, se correr o risco da perda da coisa; isto porque, reafirme-se, o depositário deve guardar bem alheio, e não bem próprio. (AZEVEDO, 2000, p. 124).

Por sinal, a equiparação do devedor fiduciário ao depositário sempre foi objeto das mais contundentes críticas ao Decreto 911/69. Para Waldirio Bulgarelli, o legislador foi particularmente infeliz para o devedor que "em um passe de mágica" deixou de ser comprador para tornar-se depositário.

$\mathrm{Na}$ raiz de tudo isso, sugere: "naturalmente foi mais fácil enquadrá-lo, por um Decreto-lei, entre os depositários, do que reformar a Constituição, admitindo mais um caso de prisão por dívida" (BULGARELLI, 2000, 311).

De se notar que a posição do devedor sequer corresponde propriamente a de depositário naquilo que lhe poderia ser favorável, notadamente o exercício do direito de retenção, que lhe é vedado (DA LUZ, 1999, p. 329).

Seja como for, embora ainda possível a conversão do devedor em depositário, a suposta eficácia coercitiva dessa medida restou quase completamente diluída em função do entendimento que veio a se pacificar no âmbito do Supremo Tribunal Federal no sentido de que são inconstitucionais todas as formas de prisão civil com pressuposto em relação jurídica de depósito ${ }^{24}$. Assim, um instituto contratual não invalida nem prejudica a existência do outro, sobretudo em função dos diferentes efeitos processuais que emanam. É o caso, por exemplo, da impossibilidade do uso da ação de depósito quando se esteja diante da reserva de domínio.

Como dito, certas compras e vendas necessitam de um maior aporte de crédito porque o bem apresenta valor maior (carros, maquinário etc.). Nesses casos, o financiamento é oportunizado por instituições que operam no mercado de capitais (que funcionam como intermediárias) e continua sendo regido pelo Decreto-lei 911/69, cujo âmbito de aplicabilidade é voltado exatamente para reger essas operações (GONÇALVES, 2006, p. 238).

Assim, o ordinário é que o Código Civil seja aplicado aos financiamentos, ou simplesmente nas vendas diferidas no tempo, quando realizados fora do mercado financeiro e de capitais. Ao mesmo tempo, as disposições do Decreto-lei 911/69 podem ser levadas a efeito apenas pelas pessoas jurídicas autorizadas a atuar no mercado financeiro e de capitais, embora tenha existido quem defendesse sua aplicação análoga para entidades que com elas guardassem proximidade (MARTINS, 1997, p. 187) 25. Por outro lado, é igualmente possível que uma instituição financeira possa contratar, nos termos do art. 528 do Código Civil de 2002, cláusula de reserva de domínio propriamente dita, ficando, assim, a regência do pacto realizada pela legislação civil ordinária:

\footnotetext{
Se o vendedor receber o pagamento à vista, ou, posteriormente, mediante financiamento de instituição do mercado de capitais, a esta caberá exercer os direitos e ações decorrentes do contrato, a benefício de qualquer outro. A operação financeira e a respectiva ciência do comprador constarão do registro do contrato.
}

Naturalmente, sendo a venda com reserva de domínio, ainda que com induvidosa característica financeira, realizada por pessoa que não esteja autorizada a funcionar no mercado a que se refere a Lei no 4.728/65, não será permitida a cobrança de juros além da limitação prevista

24 Enunciado n 25 da Súmula Vinculante do STF: "É ilícita a prisão civil de depositário infiel, qualquer que seja a modalidade do depósito."

25 A Lei no 4.728, de 14 de julho de 1965, ao disciplinar o mercado financeiro e de capitais estabeleceu, em seu art. 5o, os entes autorizados a nele atuar (sistema de distribuição de títulos ou valores mobiliários). 
no art. $1^{\circ}$ do Decreto $n^{\circ} 22.626$, de 07/04/1933, como já teve oportunidade de decidir o Superior Tribunal de Justiça ${ }^{26}$. Igualmente, não pode ser beneficiada com qualquer outra disposição que apenas seja dirigida a entidade que integre o Sistema Financeiro Nacional, como o reajuste das prestações do arrendamento mercantil segundo a variação cambial, conforme a exceção prevista no art. 60 da Lei no 8.880/9427.

\section{Alienação da Coisa Pelo Comprador}

Há, na doutrina, uma consolidada corrente contrária a que o comprador possa alienar a coisa antes de integralizado o preço.

A explicação é óbvia: conquanto goze da posse, o comprador ainda não é o proprietário, logo não poderia transferir domínio que ainda não estava associado em definitivo a seu patrimônio jurídico (nemo plus iuris ad alium transferre potest quam ipse habet) ${ }^{28}$.

Em sentido contrário, Caio Mário da Silva Pereira e Miguel Maria da Serpa Lopes sustentam a possibilidade de venda pelo comprador (PEREIRA, 2007, p. 233). O argumento aqui é que o ônus decorrente do pacto adjeto igualmente é transferido (VENOSA, 2005, p. 101).

Essa é a posição adotada pela dogmática francesa. A jurisprudência da Corte de Cassação francesa historicamente abona essa interpretação, como pode ser observado do aresto (abaixo transcrito) que foi lavrado nos autos (pourvoi) de nº 08-10241, em 16 de junho de 2009, por sua Câmara Comercial29.

Muito embora analisando o problema do excesso na cobrança em uma revenda numa operação que originariamente contava com a cláusula de reserva de domínio, reconheceu aquele renomado tribunal, preliminarmente, a plena validade do pacto acessório, bem como a possibilidade de alienação da coisa a terceiro, podendo o proprietário cobrar o preço, ou reivindicar a coisa de quem a esteja possuindo ${ }^{30}$.

Nada obstante o rigor da primeira construção, deve-se abrandá-la em face da maior conveniência prática da segunda tese.

A tal propósito, é possível superar o impasse lógico-jurídico (da insuficiência de poderes para a realização da venda pelo comprador) por três formas distintas: a) considerando-se a venda apenas da posse, assumindo o terceiro adquirente os riscos inerentes à aquisição da propriedade; b) em virtude do novel instituto da assunção de dívida (art. 299 do CC) e, ainda; c) por meio da ainda não positivada, no Direito brasileiro, porém já amplamente conhecida (na doutrina) cessão da posição contratual ${ }^{31}$.

26 Cf. STJ. REsp 489.658/RS, Rel. Ministro BARROS MONTEIRO, QUARTA TURMA, julgado em 05/05/2005, DJ 13/06/2005, p. 310.

27 Cf. STJ. AgRg no Ag 845.988/SP, Rel. Ministro ARI PARGENDLER, TERCEIRA TURMA, julgado em 02/09/2008, DJe 18/11/2008.

28 "Possuindo a título precário, não lhe é permitido alienar a coisa. Pode, no entanto, praticar os atos conservatórios da posse, defendendo-a por meio dos interditos." (GOMES, 1994, p. 265).

29 Essa solução está agora legislada no atual art. 2372 do Código Civil: "Le droit de propriété se reporte sur la créance du débiteur à l'égard du sous-acquéreur ou sur l'indemnité d'assurance subrogée au bien."

30 Essa solução está agora legislada no atual art. 2372 do Código Civil: "Le droit de propriété se reporte sur la créance du débiteur à l'égard du sous-acquéreur ou sur l'indemnité d'assurance subrogée au bien."

31 "Actualmente no se duda de que se debe considerar a la cesión del contrato como un instituto distinto de la cesión de créditos o de deudas, que consiste en un único negocio translativo del complejo de derechos y deberes que están adheridos a la calidad de parte, y que están unidos por la posición contractual." (LORENZETTI, 2004, p. 492) 
Assim, nada impede que o comprador possa não apenas transferir a dívida a um terceiro, como também lhe será possível ceder a própria posição de comprador, com todos os ônus e vantagens respectivas (LÔBO, 2011, p. 262). Naturalmente, tanto num caso como em outro, haverá o vendedor (ou o financiador) de assentir expressamente na substituição do comprador originário (GONÇALVES, 2006, p. 240).

A presença do vendedor neste negócio jurídico é requisito de eficácia, para que a cessão, quer da dívida, quer da posição contratual, lhe seja oponível (LORENZETTI, 2004, p. 493). Não tendo a alienação sido aviada pelo vendedor proprietário, este poderá buscar a coisa, de quem a detenha injustamente.

Subsiste, entretanto, a questão dos efeitos da posse para o adquirente. Estando a cessão do contrato ratificada pelo vendedor proprietário, não há dúvidas de que a posse será tanto justa como de boa-fé, pelo menos até a configuração de um possível inadimplemento pelo devedor.

Se, porém, não há a ratificação do vendedor em qualquer uma dessas situações?

Sendo transmitida apenas a posse da coisa, visto que impossível a transmissão da propriedade, o subcomprador ficará sujeito à atuação do credor inicial, que poderá, obviamente, exercer as ações a que faz jus contra sua pessoa.

Ferrara já falava da obrigação (dovere) do comprador em manter a coisa perto de si e, se por eventualidade a entrega a um terceiro, o vendedor poderia apenas postular que a coisa voltasse para sua posse direta, mas também poderá postular a resolução do contrato, com o uso dos remédios processuais já comentados ${ }^{32}$.

A solução parece, entretanto, excessivamente privatista e pode não ter em mente a função social do contrato, inclusive como mecanismo de trânsito de riquezas. Imagine-se uma obra de arte comprada com reserva de domínio.

Não seria legítimo ao comprador dá-la em comodato para uma instituição com o fim de exibi-la em público? Tomando conhecimento do subcontrato, poderia o vendedor solicitar alguma garantia adicional, ou, dependendo do caso, o embargo da entrega da coisa, mas não parece ajustado concluir que possa o contrato ser resolvido, salvo se existir, dependendo da natureza da avença, cláusula específica nesse sentido.

Naturalmente, conclusão diversa dá-se para os contratos em que a propriedade é fiduciária, quer a denominada paritária, quer as especiais. Aqui, o Código Civil (art. 1.363), malgrado todas as críticas em sentido contrário, equiparou o fiduciante ao depositário, vedando, por força de tal disposição, que possa apartar-se da posse da coisa.

Sob essa perspectiva explica-se ainda a vigência do $\S 2^{\circ}$, na atual redação do art. 66-B da Lei n ${ }^{\circ} 4.728 / 66$, quando diz que o devedor que alienar, ou der em garantia a terceiros, coisa que já alienara fiduciariamente em garantia, ficará sujeito à pena prevista no crime de estelionato (art. 171, $\S 2^{\circ}$, I, do Código Penal).

Por fim, hipótese interessante diz respeito à possibilidade de acessão de um bem móvel a um imóvel, quando ainda em execução o contrato com cláusula de reserva de domínio.

32 "Abbiamo detto che il compratore oltre un diritto ha anche un dovere al possesso. Infatti secondo il regolamento di esecuzione egli è tenuto a conservare la cosa presso di sé; se la consegna ad un terzo, il venditore può limitarsi a chiedere che essa ritorni nel possesso della controparte, poiché essa sola è autorizzata al possesso di fronte a lui; come può chiedere la risoluzione del regolamento e revindicare la cosa" (FERRARA, 1934, p. 95). 
O Código Civil francês em seu art. 2.370 traz regra específica a respeito, dizendo ser permitida tal incorporação quando puder ser o bem incorporado e separado posteriormente sem sofrer danos ${ }^{33}$.

Essa não parece uma hipótese absurda, mas, muito antes, prática. Na compra de vários produtos, cujo uso seja residencial, é possível acudir a um pacto adjeto de reserva de domínio, sendo que o uso do produto mesmo está associado a uma incorporação (no que se difeririam das pertenças - art. 94 do Código Civil) a um outro bem.

\section{Conclusão}

Após a comparação do pacto adjeto de reserva de domínio com as disposições atualmente vigentes em outros países, pode-se dizer que a Lei Civil de 2002 foi particularmente fiel ao modelo estabelecido pelo Código Civil italiano de 1942.

Nada obstante, o pacto de reserva de domínio é atualmente uma das ferramentas de maior prestígio e fácil aplicação para a garantia dos negócios jurídicos que envolvem a alienação da propriedade em prestações. Por tal razão, foi objeto de referência especial na Diretiva 2000/35 da Comunidade Europeia.

Em virtude dessa novel configuração do pacto de reserva de domínio, a um só tempo mais ampla e dinâmica, apresenta-se de interesse repensar os institutos incorporados pelo Código de 2002, de modo a modernizar e compatibilizar a cláusula adjeta aos modelos presentemente em voga.

Dentre outras, sugere-se as seguintes reflexões, para não dizer mudanças, no Direito brasileiro em relação à cláusula de reserva de domínio:

Incidência sobre imóveis e bens fungíveis: não é da essência da cláusula sua limitação exclusivamente para bens infungíveis. Além de não se visualizar qualquer prejuízo na expansão do âmbito de incidência do pacto adjeto para essas duas categorias, previamente vetadas pelo legislador civil de 2002, constitui medida já aceita pelo ordenamento jurídico brasileiro quando se trata de alienação fiduciária.

Registro: poder-se-ia imaginar um valor mínimo que isentasse o vendedor da necessidade de efetuar o registro do contrato, ou da cláusula, para que tivesse eficácia contra terceiros.

Constituição em Mora: uma análise mais rigorosa, conduziria à simbiose das disposições do art. 525 com a regra geral no art. 397, parágrafo único do Código Civil, de modo que também a notificação extrajudicial venha a ser passível de ser utilizada para constituir o devedor em mora.

Resolução do contrato: a exemplo do Código Civil italiano, seria salutar a existência de uma regra que disciplinasse com maior precisão o momento da ocorrência da resolução contratual, ou, pelo menos, que fosse incorporada a possibilidade expressa de purgação da mora em qualquer momento, como já acontece com os contratos de alienação fiduciária em garantia (art. $3^{\circ}, \S 2$ o, do Decreto no 911/69, dada pela Lei no 10.931/94).

Venda da coisa pelo comprador durante a execução do contrato com cláusula de reserva de domínio: as inovações do Direito francês a esse respeito poderiam ser objeto de

33 'L'incorporation d'un meuble faisant l'objet d'une réserve de propriété à un autre bien ne fait pas obstacle aux droits du créancier lorsque ces biens peuvent être séparés sans subir de dommage." 
incorporação pelo Direito brasileiro, já que, sem desconhecer a realidade social, dão alguma sistematicidade a esse intrincado problema, de modo que seria possível a alienação, senão da coisa, pelo menos da posse dela, mesmo pendente a cláusula de reserva de domínio entre o vendedor originário e o (sub)vendedor posterior, desde que fosse acompanhado do necessário ônus real para sua reivindicação contra o terceiro adquirente.

\section{REFERÊNCIAS}

ALVES, José Carlos Moreira. Da Alienação Fiduciária em Garantia. 2. ed. Rio de Janeiro: Forense, 1979.

AZEVEDO, Álvaro Villaça. Teoria Geral dos Contratos Típicos e Atípicos. Curso de Direito Civil. 3. ed. São Paulo: Atlas, 2009.

. Prisão Civil por Dívida. 2. ed. São Paulo: RT, 2000.

BESSONE, Darcy. Da Compra e Venda. Promessa e reserva de domínio. Belo Horizonte: Bernardo Álvares, 1960.

BULGARELLI, Waldírio. Contratos Mercantis. 13. ed. São Paulo: Atlas, 2000.

DA LUZ, Aramy Dornelles. Negócios Jurídicos Bancários. O banco múltiplo e seus contratos. São Paulo: Juarez de Oliveira, 1999.

DO COUTO E SILVA, Clóvis. A obrigação como processo. Rio de Janeiro: FGV, 2006.

FERRARA, Massimo. La Vendita a Rate con Riserva di Proprietà. Napoli: Nicola Jovene, 1934.

GAGLiAnO, Pablo Stolze \& PAMPLONA FILHO, Rodolfo. Novo Curso de Direito Civil. Contratos. V. IV. Tomo II. São Paulo: Saraiva, 2008.

GALGANO, Francesco. Trattato di Diritto Civile. V. II. Milano: CEDAM, 2010.

GOMES, Orlando. Alienação Fiduciária em Garantia. 4. ed. São Paulo: RT, 1975.

. Contratos. 13. ed. Atual. por Humberto Theodoro Júnior. Rio de Janeiro: Forense, 1994.

GONÇALVES, Carlos Roberto. Direito Civil Brasileiro. Contratos e atos unilaterais. 2. ed. V. III. São Paulo: Saraiva, 2006.

ITURRASPE, Jorge Mosset. Contratos. Santa Fé: Rubinzal-Culzoni, 2007.

LISBOA, Roberto Senise. Manual de Direito Civil. Contratos e declarações unilaterais. Teoria geral e espécies. 3. ed. São Paulo: RT, 2005.

LÔBO, Paulo. Direito Civil. Contratos. São Paulo: Saraiva, 2011.

LORENZETTI, Ricardo Luiz. Tratado de los Contratos. Parte general. Santa Fé: Rubinzal-Culzoni, 2004.

MARQUES, Cláudia Lima. Contratos no Código de Defesa do Consumidor. O novo regime das relações contratuais. 4. ed. São Paulo: RT, 2002. 
MESSINEO, Francesco. Doctrina General del Contrato. Trad. Santiago Sentis Melendo et alli. Tomo I. Buenos Aires: Ediciones Jurídicas Europa-América, 1986.

MARTINS, Fran. Contratos e Obrigações Comerciais. 14. ed. Rio de Janeiro: Forense, 1997.

MONTEIRO, Washington de Barros. Curso de Direito Civil. Direito das obrigações. $2^{\mathrm{a}}$ parte. Dos contratos em geral. Das várias espécies de contrato. Dos atos unilaterais. Da responsabilidade civil. 34. ed. Atual. por Carlos Alberto Dabus Maluf \& Regina Beatriz Tavares da Silva. São Paulo: Saraiva, 2003.

PEREIRA, Caio Mário da Silva. Instituições de Direito Civil. Contratos. 12. ed. Atual. por Regis Fichtner. Rio de Janeiro: Forense, 2007.

RESTIFFE NETO, Paulo \& RESTIFFE, Paulo Sérgio. Alienação Fiduciária e o Fim da Prisão Civil. São Paulo: RT, 2007.

RIZZARDO, Arnaldo. Contratos. 10. ed. Rio de Janeiro: Forense, 2010.

RODRIGUES, Silvio. Direito Civil. Dos contratos e das declarações unilaterais da vontade. 29. ed. São Paulo: Saraiva, 2003.

VARELA, João de Matos Antunes. Das Obrigações em Geral. 7. ed. V. I. Coimbra: Almedina, 1991 .

. Das Obrigações em Geral. 7. ed. V. II. Coimbra: Almedina, 1999.

VENOSA, Sílvio de Salvo. Direito Civil. Contratos em espécie. 5. ed. São Paulo: Atlas, 2005.

WALD, Arnoldo. Direito Civil Brasileiro. Obrigações e contratos. São Paulo: Saraiva, 2004.

\section{CONTROVERSIAL ASPECTS OF SALE AGREEMENT WITH TITLE RETENTION}

Abstract: This article discusses the main features of the sale contract with title retention according to the Brazilian Civil Code of 2002, facing European models, with which the Brazilian law has affinities, before concrete answers to problems raised.

Keywords: Contract with reserve of ownership. Brazilian Civil Code of 2002. Trust property and chattel mortgage. Controversial aspects. Comparative law. Title retention.

Data de recebimento: $\mathbf{m a r} / \mathbf{2 0 1 3}$ - Data de aprovação: dez/2013 
